\title{
Population Biology and Genetic Variation of Spongospora subterranea f. sp. subterranea, the Causal Pathogen of Powdery Scab and Root Galls on Potatoes in South Africa
}

\author{
Norman Muzhinji and Jacquie E. van der Waals ${ }^{\dagger}$ \\ Department of Plant and Soil Sciences, University of Pretoria, Hatfield, Pretoria 0028, South Africa \\ Accepted for publication 21 June 2019.
}

\begin{abstract}
Spongospora subterranea $\mathrm{f}$. sp. subterranea, causal agent of powdery scab and root galls of potatoes, occurs worldwide and is responsible for quality and yield losses in potato production in South Africa. Despite being one of the most important potato pathogens in South Africa, little information is available on the genetic structure and diversity of $S$. subterranea f. sp. subterranea, which could provide insight into the factors shaping its evolution and the role of inoculum sources in disease development. A total of 172 samples were collected from four potato growing regions in South Africa. An additional 27 samples obtained from Colombia were included for comparative purposes. The samples were screened against six informative microsatellite (simple-sequence repeat) markers. Of the 172 samples obtained from potato growing regions in South Africa, there were 75 multilocus genotypes (MLGs), only 16 of which were shared between potato growing regions, indicating substantial gene flow and countrywide dispersal of the pathogen. The presence of common MLGs among the root- and tuber-derived samples indicated a
\end{abstract}

ABSTRACT

lack of specialization of S. subterranea f. sp. subterranea to either tuber or root infection. Nei's unbiased estimates of gene diversity for the clone-corrected data were low and ranged from 0.24 to 0.38 . Analysis of molecular variance and discriminant analysis of principal components showed no population differentiation between different potato growing regions in South Africa and between root- and tuber-derived genotypes. The presence of MLGs, high considerable genotypic diversity, and failure to reject the null hypothesis of random mating in most populations are indicative of some kind of recombination, either sexual or asexual, in these $S$. subterranea f. sp. subterranea populations. Information from this study provides new insights into the genetic structure and diversity of $S$. subterranea f. sp. subterranea in South Africa. Continuous monitoring of the pathogen population dynamics will be helpful in implementing effective region-specific management strategies for the pathogen, especially in the development of resistant potato cultivars.

Spongospora subterranea f. sp. subterranea causes powdery scab on potato tubers and galls on roots and is one of the most economically important pathogens constraining potato production in South Africa (van der Waals 2015) as well as in other potato growing countries globally (Fallon et al. 2015). Powdery scab lowers the quality of potato tubers destined for fresh, processing, and seed markets. Root galls impair plant growth and productivity and contribute to inoculum build-up and pathogen perpetuation in the soil (Harrison et al. 1997). S. subterranea f. sp. subterranea is also the vector of potato mop-top virus, another pathogen of economic importance in other potato producing areas of the world (Andersen et al. 2002).

Although it has long been known that $S$. subterranea f. sp. subterranea is present in South Africa's potato growing systems (CMI 1987), it was only in the last decade that reports of powdery scab outbreaks increased in all of the potato growing regions (van der Waals 2018). This prompted renewed interest in understanding the potato-S. subterranea f. sp. subterranea pathosystem. The increase in the importance of $S$. subterranea f. sp. subterranea in potato production systems is possibly attributed to a lack of effective control strategies, increasing cultivation of potato

†Corresponding author: J. E. van der Waals; jacquie.vanderWaals@up.ac.za

Funding: The National Research Foundation is acknowledged for supporting this study and purchasing the DNA sequencing instrument (grant UID 78566) used at the University of Pretoria.

*The $\boldsymbol{e}$-Xtra logo stands for "electronic extra" and indicates that three supplementary figures and one supplementary table are published online.

The author(s) declare no conflict of interest.

(C) 2019 The American Phytopathological Society cultivars susceptible to $S$. subterranea f. sp. subterranea and changes in farming systems such as increased frequency of irrigation (Simango and van der Waals 2017). Most of the management strategies used by potato growers to minimize the risk of $S$. subterranea f. sp. subterranea diseases (e.g., crop rotation, cultural practices, and use of biocontrol agents) often give inconsistent results (Merz and Falloon 2009). Currently, there are no registered chemicals for control of $S$. subterranea $\mathrm{f}$. $\mathrm{sp}$. subterranea on potatoes in South Africa (Simango and van der Waals 2017). The only reliable method for controlling S. subterranea f. sp. subterranea on potato is planting diseasefree seed tubers in uncontaminated fields. Breeding potato cultivars resistant to $S$. subterranea $\mathrm{f}$. sp. subterranea has been proposed as an important long-term and sustainable component of integrated management of the pathogen (Merz et al. 2004). However, development of resistant cultivars has been hindered by a lack of tion, as well as limited knowledge of the population biology and genetics of the pathogen (Merz and Falloon 2009).

Knowledge of the population genetic structure and reproductive biology of a pathogen is needed to understand the evolutionary processes and ecological factors that shape pathogen populations and influence their biological adaptation (Linde et al. 2002). Population biology provides useful insights into the origin, sources of inoculum, routes of introduction, and phylogeography of the pathogen (Linde et al. 2002). It also guides plant breeders in the use of appropriate pathogen isolates for screening germplasm for resistance and informs the development or improvement of effective and durable disease management strategies (Gau et al. 2013; McDonald and Linde 2002; Qu and Christ 2006).

Population genetic structure refers to the patterns of genetic diversity within and between populations resulting from the interactions among forces shaping pathogen evolution, including potato germplasm resistant to both powdery scab and root infec- 
natural selection, mutation, genetic drift, recombination, and migration (McDonald and Linde 2002). All of these forces interact to determine the evolution trajectory of a pathogen and to generate the genetic structure of its populations, hence facilitating its adaptation to environmental changes and ecological niches. Knowledge of factors that drive pathogen variability is critical to disease management, owing to the significant impacts thereof on the epidemiology of pathogen populations. For example, pathogens with a mixed reproduction system of clonality and recombination have a higher potential of gene flow and mutation rates than asexually reproducing microorganisms (McDonald and Linde 2002; Milgroom 2015). Recombination enhances the ability of the pathogen to evolve rapidly in response to changes in environmental conditions and control strategies such as the use of resistant cultivars and the application of chemicals (Linde et al. 2002).

The life cycle of $S$. subterranea $\mathrm{f}$. sp. subterranea begins with the germination of overwintering resting spores to release biflagellated zoospores (Merz and Falloon 2009). The zoospores swim to the roots and penetrate and infect the epidermal cells or root hairs to produce multinucleate sporangial plasmodia, which develop within the root and become enclosed into multinucleate compartments that eventually develop to form zoosporangia (Falloon 2008). Once in the host tissue, the pathogen undergoes several inoculum-producing cycles (polycyclic), resulting in new infections in the plant. Given that zoospores are confined to the soil and only infect hosts in close proximity, latently infected potato tubers are the most likely predominant inoculum source that contributes toward the longdistance dissemination of the pathogen into new areas (Merz and Falloon 2009). In the S. subterranea f. sp. subterranea life cycle, the sexual stage has not yet been identified, but the characteristics of the population genetic structure obtained by Gau et al. (2013) are indicative of a pathogen undergoing recombination, conflicting with the theoretical expectation of a clonally reproducing pathogen.

Conventionally, the size of sporosori has been used as an indicator of variation within $S$. subterranea $\mathrm{f}$. sp. subterranea populations (Qu and Christ 2006). However, the variation in size of the sporosori is not heritable and is usually affected by environmental conditions and the nutritional status of the soil $(\mathrm{Qu}$ and Christ 2004). Molecular methods have become an indispensable tool in elucidating the population structure and genetic variation of economically important plant pathogens (McDonald 1997). Bulman and Marshall (1998) and Qu and Christ (2004) identified two genetically different groups of $S$. subterranea $\mathrm{f}$. sp. subterranea by PCR using the internal transcribed spacer (ITS) region. Both studies classified S. subterranea f. sp. subterranea isolates into ITS type I and ITS type II. However, the ITS region is conserved intraspecifically and does not reveal a lot of genetic variation within populations. Gau et al. (2013) characterized S. subterranea f. sp. subterranea populations collected around the globe using microsatellites (simple-sequence repeats [SSRs]). The native South American populations had higher genetic diversity and population differentiation than the introduced European, Asian, and African populations, which were characterized by high gene flow within geographic locations. These studies assessed the genetic structure of $S$. subterranea f. sp. subterranea by comparing populations from different continents (Gau et al. 2013) and until now, no studies have been done to determine the population genetic structure of $S$. subterranea f. sp. subterranea at a local scale or to investigate whether root- and tuber-infecting $S$. subterranea f. sp. subterranea populations are genetically differentiated.

In South Africa, it is unknown how $S$. subterranea f. sp. subterranea populations are structured. The aims of this study were therefore to evaluate the population structure and genetic variation of $S$. subterranea f. sp. subterranea populations from different potato growing regions in South Africa and to investigate whether the root- and tuber-derived S. subterranea f. sp. subterranea samples are genetically differentiated. Knowledge from this type of work is important for understanding the genetic diversity of the pathogen and its evolutionary adaptive potential, which is necessary in designing effective and sustainable disease management programs for controlling $S$. subterranea $\mathrm{f}$. sp. subterranea in South Africa.

\section{MATERIALS AND METHODS}

Sampling of S. subterranea f. sp. subterranea. In total, 172 samples (consisting of 79 from root galls and 93 from powdery scab lesions) were collected from four major potato growing regions of South Africa: namely, Limpopo, Sandveld, KwaZulu-Natal, and Mpumalanga (Fig. 1). Samples were collected from commercial potato farms. Fields with a known history of powdery scab disease were selected, one each in Limpopo, KwaZulu-Natal, and Sandveld and two in Mpumalanga. The number of sampled tubers and roots ranged from 30 to 50 per growing region. Roots were sampled 7 to 8 weeks after the emergence of plants and from tubers at the harvest of each field. In both cases, hierarchical sampling of fields was used. The sampling locations were selected to represent the climatic diversity of South Africa, because Limpopo and Mpumalanga have a temperate climate with dry winters and rainy summers and KwaZulu-Natal has a warm, humid coastal climate. In contrast, the Sandveld has a Mediterranean climate with dry warm summers and rainy winters (Botai et al. 2018). An additional 27 S. subterranea $\mathrm{f}$. sp. subterranea samples (18 from root galls and nine from powdery scab lesions) from Colombia were included for comparative purposes. The Colombian $S$. subterranea f. sp. subterranea populations were reported to be the most diverse among all of the populations used by Gau et al. (2013) and were therefore used as an outgroup in this study.

DNA extraction and amplification. To obtain $S$. subterranea f. sp. subterranea samples, $10-\mathrm{mm} \times 5-\mathrm{mm}$ tissue pieces were excised from powdery scab lesions using a sterile scalpel blade, and $50 \mathrm{mg}$ of galls on the roots were used for DNA extraction for each sample. Total genomic DNA was extracted using the ZR fungal DNA kit (Zymo Research Corporation) following the manufacturer's recommendations. DNA was quantified using a fluorometer (Qubit 20; Invitrogen Inc.) and stored in Tris-EDTA buffer at $-20^{\circ} \mathrm{C}$. Genomic DNA samples were examined for integrity after electrophoresis on $0.8 \%$ (wt/vol) agarose gel in Tris acetate-EDTA (TAE) containing $0.001 \%$ (vol/vol) GelRed (Biotium Inc.). The working concentration of DNA was adjusted to $20 \mathrm{ng} / \mu \mathrm{l}$ prior to PCR. The presence of $S$. subterranea $\mathrm{f}$. sp. subterranea DNA was confirmed by using ITS-derived primers Sps 1 ( $5^{\prime}-$ CCTGGGTGCGATTGTCTGTT- $3^{\prime}$ ) and Sps2 (5'-CACGC CAATGGTTAGAGACG-3') (Bulman and Marshall 1998). PCR was performed in a total volume of $25 \mu \mathrm{l}$ containing $1 \mu \mathrm{l}$ of genomic DNA (20 ng), $14.5 \mu \mathrm{l}$ of MyTaq PCR master mix (Bioline), and $0.8 \mu \mathrm{m}$ of reverse and forward primers. The cycling parameters were $94^{\circ} \mathrm{C}$ for $1 \mathrm{~min}$, then 30 cycles of $94^{\circ} \mathrm{C}$ for $15 \mathrm{~s}, 60^{\circ} \mathrm{C}$ for $30 \mathrm{~s}$, and $72{ }^{\circ} \mathrm{C}$ for $45 \mathrm{~s}$, followed by $72^{\circ} \mathrm{C}$ for $10 \mathrm{~min}$. Reaction products were run using electrophoresis on a $1.5 \%$ agarose gel in $1 \times$ TAE buffer and visualized with GelRed using a Bio-Rad gel documentation system. As an obligate biotrophic pathogen, samples were collected from single lesions, which we assume arose from the same infection event and potentially contain predominantly a single genotype. Gau et al. (2015) noted that only the predominant genotype is detected in a sample by conventional PCR and minor genotypes are detected only when the PCR products of inoculum samples are cloned.

Microsatellite analysis. For microsatellite analysis, genomic DNA from 199 samples was used. To improve comparability between studies, populations were amplified using the same six microsatellite loci described by Gau et al. (2013). The forward primer of each SSR marker was labeled with VIC, FAM, NED, or PET (Thermo Fisher Scientific). For each microsatellite marker, a $25-\mu \mathrm{l}$ PCR reaction mix containing $1 \mu \mathrm{l}$ of genomic DNA (20 ng), 
14.5 $\mu \mathrm{l}$ of MyTaq PCR master mix (Bioline), $0.6 \mu \mathrm{m}$ of locusspecific reverse primer, and $0.6 \mu \mathrm{m}$ of each corresponding fluorescent-labeled forward primer (Supplementary Table S1) was used. PCR amplification included denaturation at $95^{\circ} \mathrm{C}$ for $3 \mathrm{~min}, 35$ cycles of denaturation at $95^{\circ} \mathrm{C}$ for $30 \mathrm{~s}$, annealing at $55^{\circ} \mathrm{C}$ for $30 \mathrm{~s}$, and extension at $72^{\circ} \mathrm{C}$ for $45 \mathrm{~s}$, followed by $72^{\circ} \mathrm{C}$ for $7 \mathrm{~min}$ on the final cycle. After amplification, primers containing different fluorescent dyes were multiplexed in one panel. Subsequently, the multiplexed amplicons $(1 \mu \mathrm{l})$ were mixed with $9 \mu \mathrm{l}$ of Hi-Di formamide and $0.1 \mu \mathrm{l}$ of GeneScan $500 \mathrm{LIZ}$ size standards (Applied Biosystems). All samples were denatured for $3 \mathrm{~min}$ at $96^{\circ} \mathrm{C}$ and fragments were separated by capillary electrophoresis on an ABI $3130 x 1$ sequencer at the Bioinformatics Unit of the University of Pretoria. Allele sizes were scored and binned using GENEMAPPER version 4.0 (Applied Biosystems). A multilocus allelic data matrix based on the molecular sizes of the microsatellite markers was generated for all samples. Two of the loci designed in this study from the mitochondrial genome of $S$. subterranea f. sp. subterranea (Ciaghi et al. 2018) did not amplify consistently for all samples and were omitted from subsequent analyses. The repeatability of the SSR markers was tested by contrasting sizes of each allele at every locus for 10 samples randomly selected from all of the populations. The samples were included in every PCR and capillary electrophoresis as controls to ensure consistency across runs.
Genetic and genotypic data analysis. The population genetic data were estimated for S. subterranea f. sp. subterranea populations using two levels of stratification: (i) potato growing regions and (ii) symptom of origin. For each stratum, the population genetic statistics were obtained from the raw data. For this study, $S$. subterranea $\mathrm{f}$. sp. subterranea was treated as a functional diploid organism, based on the obtained microsatellite data (Table 1). The total number of alleles and the effective number of alleles for each locus, which is calculated as $1 r \Sigma 1 /(1-h j)$, where $r$ is the number of loci and $h j$ is the gene diversity at the jth locus (Brown and Weir 1983), were calculated using GeneAIEx version 6.5 (Peakall and Smouse 2012). All of the subsequent analyses were based on clonecorrected data unless otherwise specified.

Multilocus genotypic diversity indices were calculated using the package poppr version 2.8.1 (Kamvar et al. 2014) performed in RStudio version 1.1.456 (R Core Team 2018). Samples that had the same allelic combination at six SSR loci were considered as clones or the same multilocus genotype (MLG). To account for differences in sample sizes and allow comparisons between the populations, the expected MLG (eMLG) was also calculated, which is an approximation of the number of genotypes that would be expected at the largest shared sample size and was approximated based on rarefaction curves using 1,000 bootstrapped samples (Grünwald et al. 2003). Repeated MLGs occurring across the

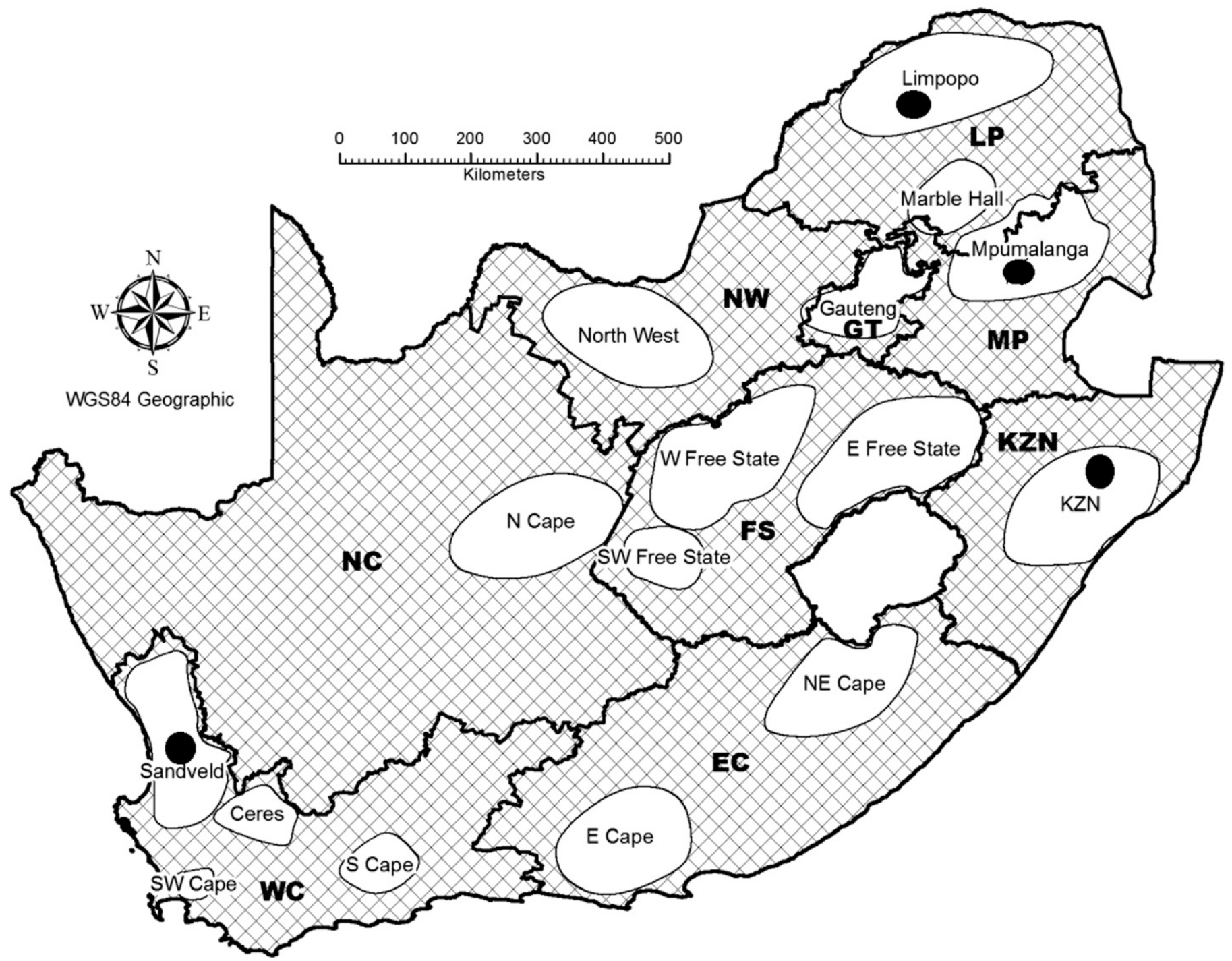

Fig. 1. Map of South Africa showing the locations of 16 potato growing regions. Black circles show the potato growing regions from which Spongospora subterranea f. sp. subterranea samples used in this study were obtained. NC $=$ Northern Cape, NW $=$ North West, LP $=$ Limpopo, GT $=$ Gauteng, MP $=$ Mpumalanga, FS = Free State, KZN = KwaZulu-Natal, WC $=$ Western Cape, and EC $=$ Eastern Cape. 
populations were identified with the function mlg.crosspop from the R package poppr (Kamvar et al. 2014). Rarefaction genotypic richness curves were constructed using the vegan package in $\mathrm{R}$ (Oksanen et al. 2017), and a genotype accumulation curve was produced with the R package poppr to assess whether the six SSR markers were able to discriminate between unique individuals (MLGs) in the data set (Kamvar et al. 2014; R Core Team 2018). To evaluate the distribution of genotypes within each population, genotypic evenness was calculated using the index, E5 (Ludwig and Reynolds 1988). E5 converges to 0 when a population is dominated by a single genotype and is equal to 1 when all genotypes occur at the same frequency (Ludwig and Reynolds 1988). Genotypic diversity was calculated using Simpson's index (D) (Simpson 1949), which estimates the probability that two randomly selected individuals would have a different MLG, and Stoddart and Taylor's index $(G)$ (Stoddart and Taylor 1988). To compare the genotypic diversity within populations of different sizes, the indices $E 5, D$, and $G$ were estimated following random sampling of the data using rarefaction in poppr with 1,000 jackknife replicates. Unbiased expected heterozygosity was also calculated, which was defined as Hexp $=\left(\left[1-\sum \mathrm{pi}^{2}\right] \times[n / n-1]\right)$, where $\mathrm{p}$ is the allele frequency at a locus and $n$ is the number of observed alleles in each locus (Grünwald et al. 2003; Nei 1978).

Multilocus gametic disequilibrium. To infer the likely reproduction strategy used by $S$. subterranea $\mathrm{f}$. sp. subterranea, the index of association $\left(I_{\mathrm{A}}\right)$ and the standardized version of $I_{A}(\mathrm{rBarD})$ were calculated on the nonclone- and clone-corrected SSR data set in the R package poppr (Kamvar et al. 2014). The $P$ value was calculated based on 999 permutations (Brown et al. 1980). The rBarD index accounts for differences in the number of loci amplified (Agapow and Burt 2001). $I_{A}$ and $\mathrm{rBarD}$ were tested for each population under the null hypothesis of linkage equilibrium (Agapow and Burt 2001). If the $I_{A}$ values are significantly different from zero $(P<0.05)$, it indicates linkage disequilibrium a hallmark of clonally reproducing populations.

Population differentiation. Pairwise comparisons of samples collected in different potato growing regions were performed to determine whether populations differed genetically as a result of adaptation within a geographic location using $F$ statistics $\left(F_{\mathrm{ST}}\right)$ (Wright 1965). Analysis of molecular variance (AMOVA) was performed to test the null hypothesis that populations of $S$. subterranea $\mathrm{f}$. sp. subterranea from different geographic regions are genetically differentiated using the pairwise $F_{\text {ST }}$ values between populations, implemented in the Arlequin 3.11 software package (Excoffier and Lischer 2010). Significance was tested using 1,000 random permutations.

Population structure analysis. The population structure of $S$. subterranea f. sp. subterranea populations from different potato growing regions was explored with discriminant analysis of principal components (DAPC), a multivariate analysis of genetic

TABLE 1. Data on the number of alleles, allele size range, and highest frequency allele found among Spongospora subterranea f. sp. subterranea samples using six microsatellite markers ${ }^{\mathrm{a}}$

\begin{tabular}{|c|c|c|c|c|c|c|c|}
\hline \multirow[b]{2}{*}{ Marker } & \multirow[b]{2}{*}{$\mathrm{Na}$} & \multirow[b]{2}{*}{$\begin{array}{l}\text { Size range } \\
\text { (bp) }\end{array}$} & \multicolumn{2}{|c|}{ Highest frequency allele } & \multirow[b]{2}{*}{ Ho } & \multirow[b]{2}{*}{$\mathrm{He}$} & \multirow[b]{2}{*}{$\mathrm{Ne}$} \\
\hline & & & Allele & $\begin{array}{c}\text { Frequency } \\
(\%)\end{array}$ & & & \\
\hline Msat6 & 4 & $200-240$ & 209 & 50 & 0.95 & 0.63 & 2.0 \\
\hline Msat45 & 3 & $265-269$ & 269 & 60 & 0.97 & 0.69 & 2.1 \\
\hline Msat84 & 8 & $240-303$ & 261 & 31 & 0.96 & 0.7 & 1.7 \\
\hline Msat103 & 4 & 179-197 & 193 & 83 & 0.98 & 0.6 & 2.1 \\
\hline Msat264.1 & 4 & $136-161$ & 136,142 & 50 & 1 & 0.56 & 1.8 \\
\hline Msat264.2 & 9 & $141-161$ & 160 & 40 & 0.9 & 0.7 & 2.7 \\
\hline Total & 33 & & & & & & \\
\hline Average & 5.5 & & & & 1 & 0.65 & 2.06 \\
\hline
\end{tabular}

a $\mathrm{Na}=$ number of microsatellite alleles per locus, Ho = observed heterozygosity, $\mathrm{He}=$ expected heterozygosity, and $\mathrm{Ne}=$ effective number of alleles. clustering among isolates (Jombart et al. 2010). DAPC assumes no prior knowledge of group membership and does not make assumptions of panmixia. The function xvaldapc from the $\mathrm{R}$ package adegenet (Jombart 2008) was utilized with the clonecorrected data set. For the DAPC analyses, the number of principal components corresponding to the lowest mean squared error was selected via crossvalidation, with a training set consisting of $90 \%$ of the data (Jombart and Collins 2015). To estimate the optimal number of genetic clusters of MLGs in the data set, the K-means procedure was implemented in the function 'find.cluster' to infer $k$, the optimal number of clusters based on all of the combined samples (Supplementary Fig. S1). $K$ was determined using an interactive model based on changes in the value of the Bayesian information criterion (Jombart et al. 2010). To assess the genetic relatedness among MLGs, a minimum spanning network (MSN) was constructed from the clone-corrected data set based on Bruvo's genetic distance (Bruvo et al. 2004). The MSN was generated using the bruvo.msn function in poppr version 2.3.0 (Kamvar et al. 2015; $\mathrm{R}$ Core Team 2017). The network was visualized using the package igraph version 1.2.1 (Csardi and Nepusz 2006).

\section{RESULTS}

Sampling and S. subterranea f. sp. subterranea identifica tion. The presence of $S$. subterranea $\mathrm{f}$. sp. subterranea DNA was confirmed by PCR with species-specific markers and all of the samples produced a 380-bp amplicon specific to S. subterranea f. sp. subterranea (Bulman and Marshall 1998). Of the 214 samples initially obtained from potato growing regions of South Africa, microsatellite data were successfully obtained from 172 samples only.

Microsatellite information content. Quantitative measures of genetic diversity were determined for all markers (Table 2). The total number of alleles amplified at the six SSR loci was 33. The mean number of alleles detected for each locus was $5.5(\mathrm{SD}=2.57)$, ranging from three alleles for markers Msat45 and Msat103 to nine alleles for marker Msat246.2 (Table 1). The effective number of alleles per locus varied from 1.7 for marker Msat84 to 2.7 for Msat246.2, with an average of 2.0. The expected heterozygosity ranged from 0.56 (Msat246.1) to 0.7 (Msat84, Msat246.2), with an average of 0.65 . The observed heterozygosity varied from 0.95 (Msat6) to 1 (Msat246.2), with an average of 0.94 (Table 1). The genetic diversity of $S$. subterranea $\mathrm{f}$. sp. subterranea revealed by the six loci evaluated in this study was low, as reflected in the average allele number per locus (4.7). The mean number of alleles detected in this study was in line with the average number of alleles and expected heterozygosity values observed in other genetic diversity studies of $S$. subterranea f. sp. subterranea (Gau et al. 2013).

Genotypic diversity. A total of 75 different MLGs were obtained among the 172 samples collected from four potato growing regions in South Africa (Table 2), representing an overall clonal fraction of $57 \%$. A total of 59 genotypes (78\%) occurred only once in the population (singleton). The overall genotype accumulation curve showed that the six primers adequately separated the 75 MLGs sampled in this study (Supplementary Fig. S2). However, the genotype accumulation curve did not reach a plateau, indicating that an additional locus would have further improved discrimination among the samples. The genotype richness of MLGs varied in each population, with a minimum of 14 MLGs in Limpopo and a maximum of 39 genotypes in the KwaZulu-Natal population (Table 2; Supplementary Fig. S3). The most frequent MLG was MLG9 and it consisted of 17 individuals (Fig. 2). A total of 16 MLGs were shared among the populations (Fig. 2). Mpumalanga had the highest number of genotypes $(n=10)$ that were shared between other potato growing regions, eight with Limpopo, four with KwaZulu-Natal, and three with the Sandveld. KwaZulu-Natal had seven shared MLGs, with five occurring in Mpumalanga and one in Limpopo. Only one genotype (MLG15) was shared between 
the two furthest potato growing regions sampled in this study, Limpopo and Sandveld (Fig. 2). Interestingly, none of the MLGs from populations in South Africa were shared with Colombian populations. To account for different sample sizes, the eMLG values for each population were determined. The eMLG values also indicated that the KwaZulu-Natal populations had the highest number of eMLGs $(n=24.1)$ and Limpopo had the lowest eMLG $(n=11.7)$.

The index of genetic evenness $(E 5)$ was high $(P>0.5)$ for all potato growing regions, indicating that MLGs are abundant in the populations, evidence of high genotypic diversity. The lowest E5 was found in the population from Limpopo (0.73) and highest in the population from Sandveld (0.95) (Table 2). The genetic diversity (Hexp) was low to moderate, with the lowest value found in the Limpopo population (0.24) and the highest in the KwaZulu-Natal population (0.38). The Shannon-Weiner index $(\mathrm{H})$ and StoddardTaylor genotypic diversity indices were highest in the population from KwaZulu-Natal $(\mathrm{H}=3.61$ and $\mathrm{G}=32.0)$, followed by Sandveld $(H=3.2$ and $G=23.2)$. The Limpopo population, where two MLGs represented 45\% (Fig. 2) of the total number of samples, had the lowest Shannon-Weiner index $(\mathrm{H}=2.3)$, genotypic diversity of 7.6, and genetic diversity of 0.28 (Table 2).

Considering the symptom of origin, root-derived isolates had a higher number of MLGs (57) and higher genotypic diversity $(\mathrm{G}=$ 34.2) than tuber-derived populations ( $\mathrm{MLGs}=44$ and $\mathrm{G}=22.4$ ) (Table 2 ; Fig. 3 ). However, the tuber-derived population had slightly higher expected heterozygosity ( 0.43 ) compared with root-derived populations (0.41) (Table 2). E5 was low in tuber-derived populations (0.68).

Tests of linkage disequilibrium. Using the nonclone- and clone-corrected data sets, the null hypothesis of random mating was not rejected in the Mpumalanga, Sandveld, and KwaZulu-Natal populations, indicating potential sexual or asexual recombination in these populations (Table 3 ). In contrast, $I_{A}$ and $\mathrm{rBarD}$ were significantly different from zero $(P<0.05)$ for both the noncloneand clone-corrected data sets in the Limpopo population, thus rejecting the null hypothesis of random mating, providing evidence of a clonal mode of reproduction.

Population differentiation. The relationship among the $S$. subterranea $\mathrm{f}$. sp. subterranea populations from different potato growing regions in South Africa was further explored using the pairwise index $\left(F_{\mathrm{ST}}\right)$ as shown in Table 4 . The pairwise index $F_{\mathrm{ST}}$ showed low genetic differentiation between regions. The Limpopo and Mpumalanga populations were not differentiated, with an $F_{\text {ST }}$ value of 0.019 , whereas the Limpopo and Sandveld populations showed greater differentiation $\left(F_{\mathrm{ST}}=0.082, P<0.05\right)$ from each other. Colombian populations were highly differentiated, with high $F_{\text {ST }}$ values (0.37 to 0.59), compared with the South African populations used in this study.

The AMOVA results indicated that $96 \%$ of the total genetic variation was attributed to genetic differences within individuals in a population $(P=0.001)$, indicating greater variation between individuals and $4 \%$ of the total genetic variation was attributed to between populations $(P=0.01)$ (Table 5$)$, suggesting very low genetic differentiation among the populations. When root- and tuber-derived isolates were considered as populations, $99 \%$ of the genetic variation was attributed to differences between individuals whereas only $1 \%$ of the explained variations was attributed to differences among populations.

Population structure. Using DAPC analyses, $S$. subterranea f. sp. subterranea populations from the four potato growing regions

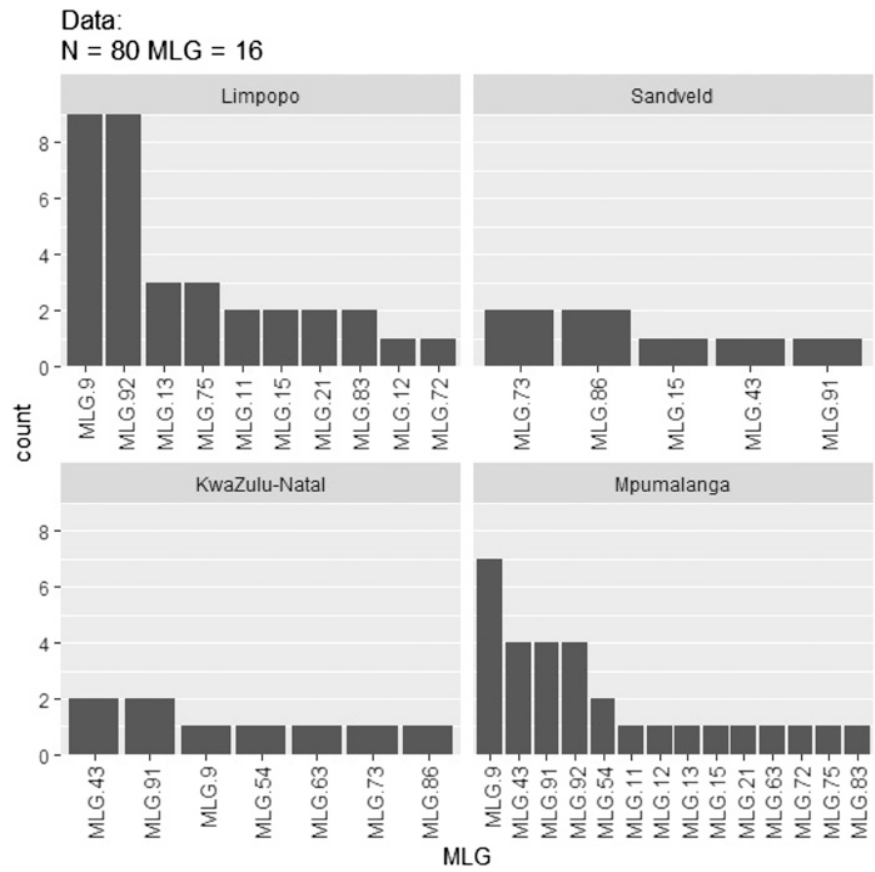

Fig. 2. Bar plot showing the abundances of multilocus genotypes (MLGs) shared between potato growing regions of South Africa. Each bar represents a unique MLG and the number of isolates in each potato growing region.

TABLE 2. Population genetic statistics of Spongospora subterranea f. sp. subterranea samples as assessed with six simple-sequence repeat markers

\begin{tabular}{|c|c|c|c|c|c|c|c|c|c|}
\hline Population & $\begin{array}{c}\text { Individual } \\
\text { samples }(n)\end{array}$ & $\mathrm{MLG}^{\mathrm{a}}$ & eMLG ${ }^{b}$ & $\mathrm{SE}^{\mathrm{c}}$ & $\mathrm{H}^{\mathrm{d}}$ & $G^{\mathrm{e}}$ & $\operatorname{Lambda}^{\mathrm{f}}$ & $E 5^{\mathrm{g}}$ & $\mathrm{Hexp}^{\mathrm{h}}$ \\
\hline \multicolumn{10}{|l|}{ Symptom of origin } \\
\hline Tubers & 79 & $44(16)$ & 44 & 0.0 & 3.48 & 22.4 & 0.96 & 0.68 & 0.43 \\
\hline Total $^{i}$ & 172 & 85 & 51 & 2.9 & 4.0 & 36.3 & 0.972 & 0.605 & 0.42 \\
\hline \multicolumn{10}{|l|}{ Region } \\
\hline Limpopo & 40 & $14(10)$ & 11.9 & 1.09 & 2.3 & 7.62 & 0.87 & 0.73 & 0.24 \\
\hline Sandveld & 37 & $26(5)$ & 21.2 & 1.19 & 3.2 & 23.20 & 0.96 & 0.95 & 0.34 \\
\hline Colombia & 27 & 15 & 15.0 & 0 & 2.63 & 12.5 & 0.92 & 0.92 & 0.41 \\
\hline Total & 199 & 100 & 22.7 & 1.80 & 4.28 & 45.36 & 0.978 & 0.621 & 0.38 \\
\hline
\end{tabular}

${ }^{a}$ MLG = number of multilocus genotypes observed. MLGs shared with other populations are shown in parentheses.

$\mathrm{b}$ eMLG = number of expected MLGs at the smallest sample size 15 based on rarefaction (Hurlbert 1971).

c $\mathrm{SE}=$ standard error based on eMLG (Heck et al. 1975).

${ }^{\mathrm{d}} \mathrm{H}=$ Shannon-Wiener index of MLG diversity (Shannon 2001).

e $G=$ Stoddart and Taylor's index of MLG diversity (Stoddart and Taylor 1988).

${ }^{\mathrm{f}}$ Lambda $=$ Simpson's index.

g E5 = evenness (Grünwald et al. 2003; Ludwig and Reynolds 1988; Pielou 1975).

${ }^{\mathrm{h}}$ Hexp = Nei's 1978 expected heterozygosity (Nei 1978).

i Only the South African populations were considered in this calculation. 
of South Africa showed no clear structuring based on geographic origin (Fig. 4). However, the South African populations clustered differently from the Colombian population used as an outgroup. The MSN based on Bruvo genetic distance analysis failed to cluster isolates according to the geographic location where they were collected (Fig. 5), which was consistent with the clustering by DAPC.

\section{DISCUSSION}

In this study, the genetic structure of 172 S. subterranea $\mathrm{f}$. sp. subterranea samples collected from four potato growing regions in South Africa was analyzed using SSR markers. An additional 27 samples from Colombia were included as an outgroup. The six SSR

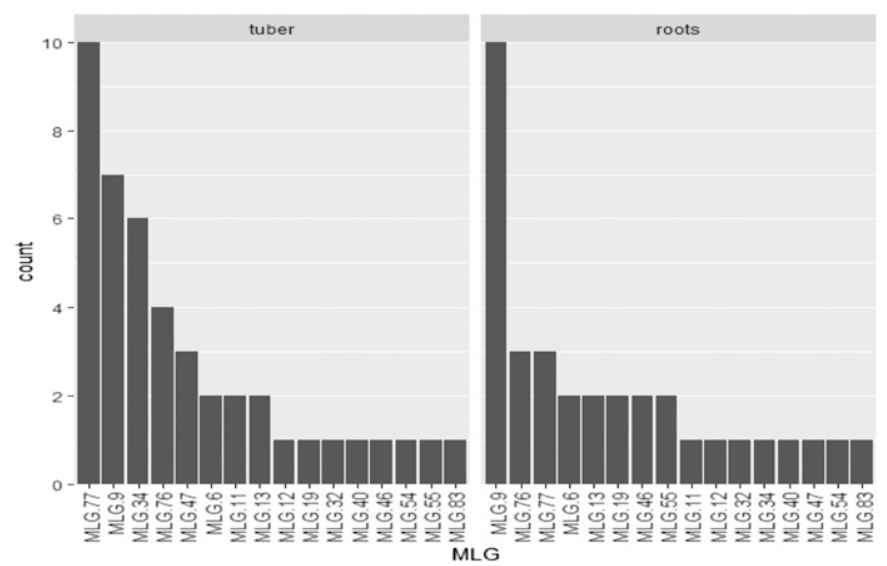

Fig. 3. Bar plot showing the abundances of multilocus genotypes (MLGs) shared between the root- and tuber-derived populations obtained from different potato growing regions of South Africa. Each bar represents a unique MLG and the number of isolates. markers used were polymorphic for the majority of the $S$. subterranea $\mathrm{f}$. sp. subterranea samples. The number of alleles and polymorphisms detected in this study were comparable to those reported for $S$. subterranea f. sp. subterranea by Gau et al. (2013). However, the genotype accumulation curve analysis showed the need for additional markers to fully discriminate samples within populations.

The $S$. subterranea f. sp. subterranea populations assessed in this study showed a low level of genotypic diversity for both the Shannon-Wiener Index of MLG diversity $(\mathrm{H})$ and Stoddart and Taylor's Index of MLG diversity (G). The highest level of genotypic diversity was found in KwaZulu-Natal followed by Sandveld, whereas the Limpopo population had the lowest $(\mathrm{H}=2.3$ and $\mathrm{G}=$ 32.01).

Of the 75 MLGs obtained from potato growing regions of South Africa in this study, 59 were site specific and 16 MLGs were shared between different growing regions sampled in this study. A single MLG was shared between the two furthest populations, Limpopo and Sandveld, while Mpumalanga shared genotypes with Limpopo and KwaZulu-Natal, which are the closest populations. The presence of common genotypes among pathogen populations indicates the occurrence of substantial gene flow among the populations, or that there is a common source of the pathogen inoculum (McDonald and Linde 2002). The high level of gene flow (low $F_{\mathrm{ST}}$ values) and the presence of multiple shared MLGs suggests that there are frequent migrations of $S$. subterranea $\mathrm{f}$. sp. subterranea between potato growing regions in South Africa. Infected tubers or other materials may be the main mechanisms responsible for long-distance dispersal of the pathogen between potato growing regions. In South Africa, potato seed tubers are produced by selected seed growers and distributed across the whole country. The interchange of infected potato seed material has been previously reported as the main mechanism of dispersal of soilborne and tuberborne pathogens (Tsror et al. 1999). The recovery of genotypes shared between populations from different geographic regions is consistent with the theoretical expectation for a species

TABLE 3. Test of association of alleles at microsatellite loci for Spongospora subterranea $\mathrm{f}$. sp. subterranea populations from different potato growing regions in South Africa ${ }^{\mathrm{a}}$

\begin{tabular}{|c|c|c|c|c|c|c|c|c|c|c|}
\hline \multirow[b]{2}{*}{ Population } & \multicolumn{5}{|c|}{ Nonclone-corrected data } & \multicolumn{5}{|c|}{ Clone-corrected data } \\
\hline & $\begin{array}{c}\text { Individual } \\
\text { samples }(n)\end{array}$ & $I_{A}$ & $P$ value & rBarD & $P$ value & $\begin{array}{c}\text { Individual } \\
\text { samples }(n)\end{array}$ & $I_{A}$ & $P$ value & rBarD & $P$ value \\
\hline \multicolumn{11}{|l|}{ Symptom of origin } \\
\hline Roots & 93 & 0.32 & 0.07 & 0.21 & 0.32 & 57 & 0.05 & 0.37 & 0.01 & 0.27 \\
\hline Total & 172 & 0.17 & & 0.22 & & 101 & 0.12 & 0.91 & 0.02 & 0.02 \\
\hline \multicolumn{11}{|l|}{ Region } \\
\hline KwaZulu-Natal & 47 & 0.68 & 0.91 & 0.01 & 0.91 & 39 & 0.08 & 0.91 & 0.02 & 0.9 \\
\hline Mpumalanga & 48 & 0.04 & 0.67 & 0.001 & 0.67 & 26 & 0.04 & 0.50 & 0.01 & 0.5 \\
\hline Colombia & 27 & 0.44 & 0.57 & 0.8 & 0.2 & 15 & 0.33 & 0.41 & 0.06 & 0.3 \\
\hline Total & 199 & 0.20 & & 0.38 & & 100 & 0.221 & & 0.03 & \\
\hline
\end{tabular}

a $I_{A}=$ index of association and $\mathrm{rBarD}=$ standardized index of association scaled for the number of loci. Asterisks indicate significantly different from zero $(P<0.05)$.

TABLE 4. Pairwise comparison of population differentiation $\left(F_{\mathrm{ST}}\right)$ among four populations of Spongospora subterranea $\mathrm{f}$. sp. subterranea in South Africa and one in Colombia ${ }^{\mathrm{a}}$

\begin{tabular}{|c|c|c|c|c|c|}
\hline \multirow[b]{2}{*}{ Population } & \multicolumn{5}{|c|}{ Population } \\
\hline & Limpopo & Sandveld & KwaZulu-Natal & Mpumalanga & Colombia \\
\hline Limpopo & 0.000 & & & & \\
\hline Sandveld & 0.082 & 0.000 & & & \\
\hline KwaZulu-Natal & 0.057 & 0.046 & 0.000 & & \\
\hline Mpumalanga & 0.019 & 0.042 & 0.053 & 0.000 & \\
\hline Colombia & 0.597 & 0.518 & 0.371 & 0.397 & 0.000 \\
\hline
\end{tabular}

${ }^{a}$ Numbers in bold show significant genetic differentiation $(P \leq 0.05)$ in pairwise comparisons based on 1,000 permutations. 
presumably reproducing asexually (Merz and Falloon 2009). However, the presence of numerous MLGs and moderate genetic diversity might suggest the presence of sexual recombination (Milgroom 2015). Little is known about the role of sexual recombination in the $S$. subterranea $\mathrm{f}$. sp. subterranea life cycle. It is, however, assumed that sporosori are the product of sexual recombination (Braselton 1995) although this has not been empirically demonstrated. Gau et al. (2015) hypothesized that sexual reproduction may be contributing to the population structure of $S$. subterranea f. sp. subterranea in introduced populations, and the populations in those regions are by now more diverse than previously reported. Furthermore, the genetic diversity maintained by S. subterranea f. sp. subterranea populations $(H \exp =0.33)$ that are evenly distributed $(E .5=0.83)$ is comparable to that described for other sexually reproducing pathogens (Njoroge et al. 2019; Pearce et al. 2019).

Furthermore, $I_{A}$ and $\mathrm{rBarD}$ indices for both the nonclone- and clone-corrected data for KwaZulu-Natal, Mpumalanga, and the Sandveld provided further indirect evidence for the occurrence of sexual or another kind of recombination in field populations of the pathogen. Similarly, Gau et al. (2013) found that the $I_{A}$ for South African S. subterranea f. sp. subterranea populations did not significantly deviate from linkage equilibrium. These findings are surprising considering that no sexual stage of $S$. subterranea $\mathrm{f}$. sp. subterranea has yet been found. Pathogens with a mixed reproductive mode pose a risk of evolving into virulent genotypes (McDonald and Linde 2002).

One of the null hypotheses of this study was that there was no population differentiation between root- and tuber-derived $S$. subterranea f. sp. subterranea samples. The tuber-derived genotypes had more MLGs $(n=51)$ than the root-derived genotypes $(n=44)$ and 13 MLGs occurred multiple times across both root- and tuber-derived populations. Genetic differentiation was not detected between root- and tuber-derived populations, suggesting a lack of reproductive isolation between the two populations, as is expected because $S$. subterranea f. sp. subterranea can cause either root galls and/or powdery scab on tubers, depending on the potato cultivar susceptibility response to the pathogen. It has been suggested that root infection and tuber infection are under different genetic control mechanisms (van de Graaf et al. 2007). Some potato cultivars are resistant to root infection, some to tuber infection, whereas other cultivars are susceptible to both or neither. Thus, the infection of tubers and/or roots by $S$. subterranea $\mathrm{f}$. sp. subterranea is cultivar dependent rather than isolate dependent. Therefore, the roots infected by $S$. subterranea f. sp. subterranea may potentially serve as a source of inoculum for powdery scab epidemics in potato fields vice versa; powdery scab lesions can serve as a source of inoculum for root gall epidemics. In contrast, however, Merz et al. (2004) reported different responses of some potato cultivars to sporosorus inoculum originating from different locations.

The substantial genotypic diversity observed for $S$. subterranea f. sp. subterranea and lack of genetic differentiation was further confirmed in the cluster analysis by DAPC and the minimum spanning tree. In both the DAPC and K-means clustering analyses, the genetic structure of $S$. subterranea $\mathrm{f}$. sp. subterranea in South Africa showed no clear clustering of populations according to the potato growing region. This partly reflects human-mediated transport of potato tubers, which can introduce $S$. subterranea $\mathrm{f}$. sp. subterranea genotypes into new areas. In the only large-scale study on genetic structure of $S$. subterranea $\mathrm{f}$. sp. subterranea to date by Gau et al. (2013), continental and intercontinental movement of the pathogen was singled out as the dominant factor of increasing genetic diversity above that of the native populations. Although no subclustering by region was observed in South African populations, they were differentiated from the Colombian population. The center of origin of any pathogen or organism is likely to have populations with higher genetic variability compared with recently established populations, because the original populations would have coevolved with the hosts for the longest time

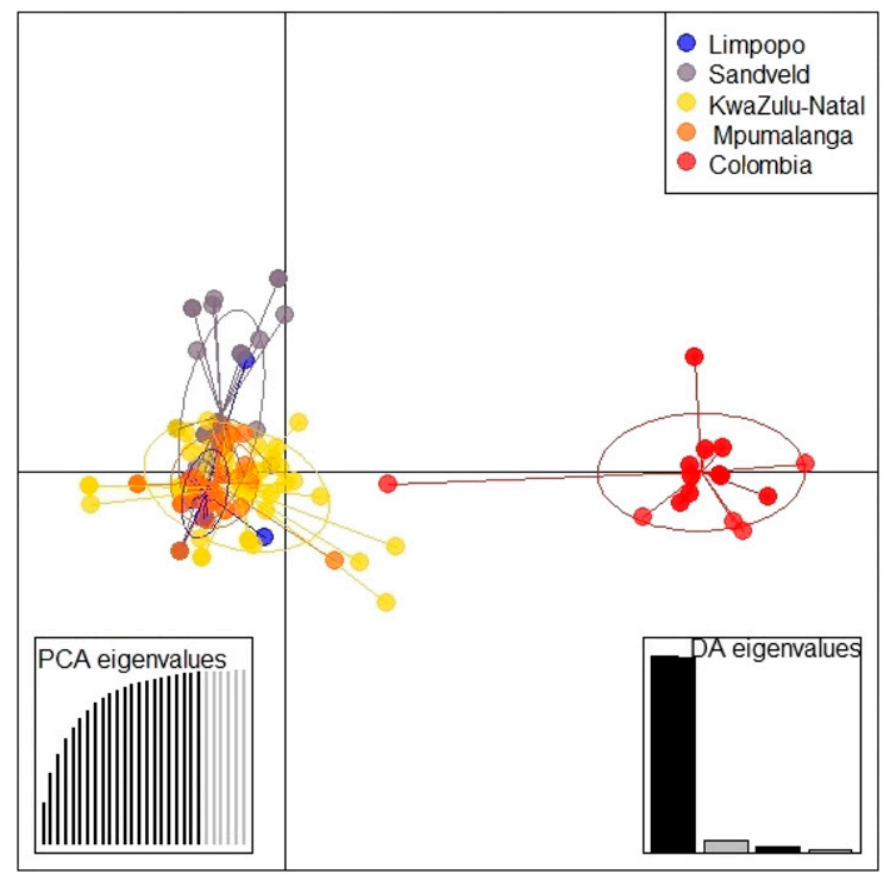

Fig. 4. Discriminant analysis of principal components (DAPC) of the first two principal components in Spongospora subterranea f. sp. subterranea samples obtained from four different potato growing regions of South Africa and from Colombia. Populations are indicated by different colors and ellipses, with dots representing multilocus genotypes (MLGs) in each population. In the bottom left and bottom right corners, insets of principal component analysis (PCA) and discriminant analysis (DA) eigenvalues are shown, respectively. The number of axes retained was 22 for the PCA and 2 for the DA.

TABLE 5. Analysis of molecular variance among Spongospora subterranea f. sp. subterranea populations and assigned genetic clusters in South Africa ${ }^{\mathrm{a}}$

\begin{tabular}{|c|c|c|c|c|c|c|c|}
\hline Source & df & SS & MS & Est. var. & Variation $(\%)$ & Fixation indices & $P$ value ${ }^{\mathrm{b}}$ \\
\hline \multicolumn{8}{|l|}{ Region } \\
\hline Among populations & 4 & 38.1 & 9.5 & 0.01 & 4 & Fst $=0.49$ & 0.01 \\
\hline Among individuals & 194 & 238.9 & 1.2 & 0.00 & 0 & Fis $=-3.39$ & 0.05 \\
\hline Total & 397 & 744.23 & & 2.95 & 100 & & \\
\hline \multicolumn{8}{|l|}{ Symptom of origin } \\
\hline Among populations & 1 & 7.6 & 7.6 & 0.036 & 1 & Fst $=0.018$ & 0.06 \\
\hline Among individuals & 170 & 231.6 & 1.36 & 0.00 & 0 & Fis $=0.8$ & 0.023 \\
\hline
\end{tabular}

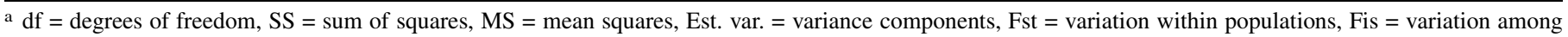
individuals, and Fit = variation within individuals among populations within groups.

b $P$ value based on 999 permutations. 
(McDonald 2015), which is likely to be the case for the Colombian populations. Potatoes and S. subterranea f. sp. subterranea originated in South America and were introduced into Europe and then acted as the "bridgehead" for subsequent distribution of the potato and its pathogens to other parts of the world, including Africa (Gau et al. 2013).

The occurrence of $S$. subterranea $\mathrm{f}$. sp. subterranea in different agroecological regions shows that $S$. subterranea $\mathrm{f}$. sp. subterranea is highly adaptable and able to thrive under a wide range of environmental conditions. It can be found in continental (Limpopo) to Mediterranean climates (Sandveld). This level of adaptation to different environments, as well as the longevity of resting spores in the soil, has made $S$. subterranea $\mathrm{f}$. sp. subterranea difficult to control. Therefore, disease control strategies should be designed at the regional scale and the spread of the pathogen from one growing region to another prevented as far as possible. The results from this study also point to the need for improved and stringent phytosanitary measures to prevent movement of $S$. subterranea f. sp. subterraneainfected material into South Africa. The history of seed trade between South Africa and Europe (Rabobank 2009) suggests that improved phytosanitary regulations and the implementation thereof may be necessary to restrict the introduction of new strains of S. subterranea f. sp. subterranea into the country.

Furthermore, since many MLGs exist in the $S$. subterranea f. sp. subterranea population in South Africa, the use of different MLGs variants in screening potato germplasm for $S$. subterranea $\mathrm{f}$. sp. subterranea resistance would ensure the success of breeding programs. The presence of a dominant genotype (MLG9) in three growing regions (namely, Limpopo, Mpumalanga, and KwaZuluNatal) suggests that this genotype may have adapted to different environmental conditions. It is therefore critical to include this dominant genotype in addition to other identified genotypes in screening and selection protocols in order to identify tolerant or resistant potato cultivars. It is, however, important to keep in mind that population dynamics of pathogens evolve and change over time and constant monitoring of genotypes in a population is necessary to make informed decisions on breeding for resistance and disease management (McDonald 2015; Milgroom 2015).

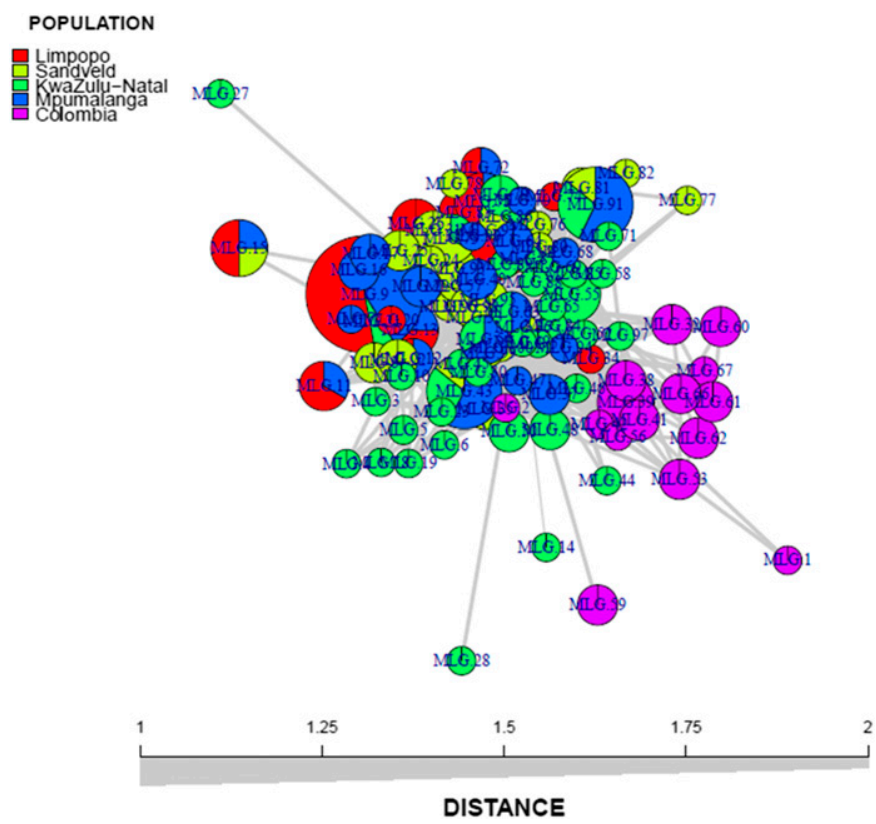

Fig. 5. Minimum spanning network tree from the clone-corrected data showing the relationships among the individual multilocus genotypes (MLGs) of Spongospora subterranea f. sp. subterranea. Each node represents a different MLG. Distances between nodes are proportional to Bruvo's distance (Bruvo et al. 2004). Node colors correspond to the population studied and sizes correspond to the number of individuals present in an MLG.
In conclusion, our results indicate that $S$. subterranea $\mathrm{f}$. $\mathrm{sp}$. subterranea populations in South Africa are clonal and recombining. This reproduction strategy allows the pathogen to preserve allelic combinations that are well adapted to certain environments, making it more difficult to manage. In this case, using evolutionary and ecological knowledge of $S$. subterranea $\mathrm{f}$. $\mathrm{sp}$. subterranea to design an integrated pest management program that combines all available strategies such as host resistance, crop rotation, and chemical control is important to manage $S$. subterranea f. sp. subterranea in potato effectively and durably. The continued monitoring of $S$. subterranea f. sp. subterranea populations will provide forewarning of any population shifts.

\section{ACKNOWLEDGMENTS}

We thank Elena Paola Gonzalez Jaimes (Politécnico Colombiano Jaime Isaza Cadavid) and Moleboheng Lekota for providing S. subterranea f. sp. subterranea samples from Colombia.

\section{LITERATURE CITED}

Agapow, P. M., and Burt, A. 2001. Indices of multilocus linkage disequilibrium. Mol. Ecol. Notes 1:101-102.

Andersen, B. A. B., Nicolaisen, M., and Nielsen, S. L. 2002. Alternative hosts for potato mop-top virus, genus Pomovirus and its vector Spongospora subterranea f. sp. subterranea. Potato Res. 45:37-43.

Botai, C. M., Botai, J. O., and Adeola, A. M. 2018. Spatial distribution of temporal precipitation contrasts in South Africa. S. Afr. J. Sci. 114: 70-78.

Braselton, J. 1995. Current status of the plasmodiophorids. Crit. Rev. Microbiol. 21:263-275.

Brown, A. H. D., Feldman, M. W., and Nevo, E. 1980. Multilocus structure of natural populations of Hordeum spontaneum. Genetics 6:523-536.

Brown, A. H. D., and Weir, B. S. 1983. Measuring genetic variability in plant populations. Dev. Plant Gen. Breed. 1:219-239.

Bruvo, R., Michiels, N. K., D’Souza, T. G., and Schulenburg, H. 2004. A simple method for the calculation of microsatellite genotype distances irrespective of ploidy level. Mol. Ecol. 13:2101-2106.

Bulman, S. R., and Marshall, J. W. 1998. Detection of Spongospora subterranea in potato tuber lesions using the polymerase chain reaction (PCR). Plant Pathol. 47:759-766.

Ciaghi, S., Neuhauser, S., and Schwelm, A. 2018. Draft genome resource for the potato powdery cab pathogen Spongospora subterranea. Mol. PlantMicrobe Interact. 31:1227-1229.

CMI. 1987. Spongospora subterranea (Wallr.) Lagerh. f. sp. subterranea. Distribution Maps of Plant Diseases. Map No. 34. CABI, Wallingford, UK.

Csardi, G., and Nepusz, T. 2006. The igraph software package for complex network research. Int. J. Complex Syst. 1695:1-9. https://igraph.org

Excoffier, L., and Lischer, H. E. L. 2010. Arlequin suite ver 3.5: A new series of programs to perform population genetics analyses under Linux and Windows. Mol. Ecol. Resour. 10:564-567.

Fallon, R. E., Merz, U., Butler, R. C., Curtin, D., Lister, R. A., and Thomas, S. M. 2015. Root infection of potato by Spongospora subterranea: Knowledge review and evidence for decreased plant productivity. Plant Pathol. 10:1-13.

Falloon, R. E. 2008. Control of powdery scab of potato: Towards integrated disease management. Am. Potato J. 85:253-260.

Gau, R. D., Merz, U., and Falloon, R. E. 2015. Infection risk potential of South American Spongospora subterranea f. sp. subterranea root gall and tuber lesion inoculum on potato (Solanum tuberosum ssp. tuberosum). Am. J. Potato Res. 92:109-116.

Gau, R. D., Merz, U., Falloon, R. E., and Brunner, P. C. 2013. Global genetics and invasion history of the potato powdery scab pathogen, Spongospora subterranea. PLoS One 8:e67944.

Grünwald, N. J., Goodwin, S. B., Milgroom, M. G., and Fry, W. E. 2003. Analysis of genotypic diversity data for populations of microorganisms. Phytopathology 93:738-746.

Harrison, J. G., Searle, R. J., and Williams, N. A. 1997. Powdery scab disease of potato-A review. Plant Pathol. 46:1-25.

Heck, K. L., Belle, G., and Simberloff, D. 1975. Explicit calculation of the rarefaction diversity measurement and the determination of sufficient sample size. Ecology 56:1459-1461.

Hurlbert, S. H. 1971. The non-concept of species diversity: A critique and alternative parameters. Ecology 52:577-586.

Jombart, T. 2008. Adegenet: An R package for the multivariate analysis of genetic markers. Bioinformatics 24:1403-1405. 
Jombart, T., and Collins, C. 2015 A tutorial for Discriminant Analysis of Principal Components (DAPC) using adegenet 2.0.0. Imperial College London. http://adegenet.r-forge.r-project.org/files/tutorial-dapc.pdf

Jombart, T., Devillard, S., and Balloux, F. 2010. Discriminant analysis of principal components: A new method for the analysis of genetically structured populations. BMC Genet. 11:94.

Kamvar, Z., Brooks, J. C., and Grünwald, N. J. 2015. Novel R tools for analysis of genome-wide population genetic data with emphasis on clonality. Front Genet. 1:208.

Kamvar, Z. N., Tabima, J. F., and Grünwald, N. J. 2014. Poppr: An R package for genetic analysis of populations with clonal, partially clonal, and/or sexual reproduction. PeerJ 2:e281.

Linde, C., Zhan, J., and McDonald, B. A. 2002. Population structure of Mycosphaerella graminicola: From lesions to continents. Phytopathology 92:946-955

Ludwig, J., and Reynolds, J. 1988. Statistical Ecology: A Primer on Methods and Computing. John Wiley and Sons, New York, NY.

McDonald, B. A. 1997. The population genetics of fungi: Tools and techniques. Phytopathology 87:448-453.

McDonald, B. A. 2015. How can research on pathogen population biology suggest disease management strategies? The example of barley scald (Rhynchosporium commune). Plant Pathol. 64:1005-1013.

McDonald, B. A., and Linde, C. 2002. Pathogen population genetics, evolutionary potential, and durable resistance. Annu. Rev. Phytopathol. 40:349-379.

Merz, U., and Falloon, R. E. 2009. Review: Powdery scab of potato-increased knowledge of pathogen biology and disease. Potato Res. 52:17-37.

Merz, U., Martinez, V., and Schwärzel, R. 2004. The potential for the rapid screening of potato cultivars (Solanum tuberosum) for resistance to powdery scab (Spongospora subterranea) using a laboratory bioassay. Eur. J. Plant Pathol. 110:71-77.

Milgroom, M. G. 2015. Population Biology of Plant Pathogens: Genetics, Ecology and Evolution. American Phytopathological Society, St. Paul, MN.

Nei, M. 1978. Estimation of average heterozygosity and genetic distance from a small number of individuals. Genetics 89:583-590.

Njoroge, A. W., Andersson, B., Lees, A. K., Mutai, C., Forbes, G., Yuen, J., and Pelle, R. 2019. Genotyping of Phytophthora infestans in eastern-Africa reveals a dominating invasive European lineage. Phytopathology 109: 670-680.

Oksanen, F. J., Blanchet, F. G., Friendly, M., Kindt, R., Legendre, P., McGlinn, D., Minchin, P. R., O’Hara, R. B., Simpson, G. L., Solymos, P., Stevens, M. H. H., Szoecs, E., and Wagner, H. 2017. Vegan: Community Ecology Package. R package version 2.4-3. https://CRAN.R-project.org/web/packages/ vegan/vegan.pdf
Peakall, R., and Smouse, P. E. 2012. GenAlEx 6.5: Genetic analysis in Excel. Population genetic software for teaching and research - an update. Bioinformatics 28:2537-2539.

Pearce, T. L., Scott, J. B., Pilkington, S. J., Pethybridge, S. J., and Hay, F. S. 2019. Evidence for sexual recombination in Didymella tanaceti populations, and their evolution over spring production in Australian pyrethrum fields. Phytopathology 109:155-168.

Pielou, E. 1975. Ecological Diversity. Wiley, New York.

Qu, X. S., and Christ, B. J. 2004. Genetic variation and phylogeny of Spongospora subterranea f. sp. subterranea based on ribosomal DNA sequence analysis. Am. Potato J. 81:385-394.

Qu, X. S., and Christ, B. J. 2006. Single cystosorus isolate production and restriction fragment length polymorphism characterization of the obligate biotroph Spongospora subterranea f. sp. subterranea. Phytopathology 96: 1157-1163.

R Core Team. 2017. R: A Language and Environment for Statistical Computing, Vienna, Austria. https://www.R-project.org

R Core Team. 2018. R: A Language and Environment for Statistical Computing. R Foundation for Statistical Computing, Vienna, Austria. https:// www.R-project.org

Rabobank. 2009. World Potato Map. Food and Agrobusiness Research and Advisory Department, Rabobank, Utrecht, Netherlands.

Shannon, C. E. 2001. A mathematical theory of communication. ACM SIGMOBILE Mobile Comput. Commun. Rev. 5:3-55.

Simango, K., and van der Waals, J. 2017. Effects of different soil treatments on the development of Spongospora subterranea $\mathrm{f}$. $\mathrm{sp}$. subterranea in potato roots and tubers. Potato Res. 1:47-60.

Simpson, E. 1949. Measurement of diversity. Nature 163:688.

Stoddart, J. A., and Taylor, J. F. 1988. Genotypic diversity: Estimation and prediction in samples. Genetics 118:705-711.

Tsror, L., Aharon, M., and Ehrlich, O. 1999. Survey of bacterial and fungal seed-borne diseases in imported and domestic potato seed tubers. Phytoparasitica 27:215-226.

van de Graaf, P., Wale, S. J., and Lees, A. K. 2007. Factors affecting the incidence and severity of Spongospora subterranea infection and galling in potato roots. Plant Pathol. 56:1005-1013.

van der Waals, J. 2015. Powdery scab series 3. Choose your armour: Cultivar susceptibility. CHIPS 2015 (Jul/Aug):48-50. http://www.potatoes.co.za/chipsonline/

van der Waals, J. 2018. Powdery scab management in South Africa. CHIPS 2018(Jul/Aug):32-36. http://www.potatoes.co.za/chips-online/

Wright, S. 1965. The interpretation of population structure by F-statistics with special regards to systems of mating. Evolution 9:393-420. 